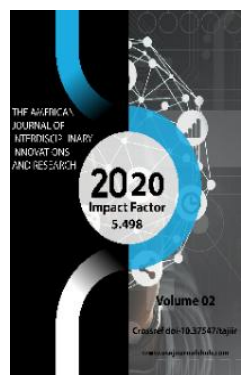

Journal Website: http://usajournalshub.c om/index,php/tajiir

Copyright: Original content from this work may be used under the terms of the creative commons attributes 4.0 licence.

\section{Territorial Aspects Of The Development Of Geodemographic Processes In Jizzakh Region}

Odil Lapasovich Mukhamedov

Candidate Of Geographical Sciences, Jizzakh State Pedagogical Institute, Uzbekistan

Davronkhoja Daverkhoja Ugli Jurakhujaev

Master's Student, Jizzakh State Pedagogical Institute, Uzbekistan

Oltinoy Bekmamatovna Shamuratova

Master's Student, Jizzakh State Pedagogical Institute, Uzbekistan

Bekzod Khamraevich Yusupov

Master's Student, Jizzakh State Pedagogical Institute, Uzbekistan

\title{
ABSTRACT
}

The article examines the absolute and relative increase in the population of the region, regional differences in births and deaths at the district level.

\section{KEYWORDS}

Demographic situation, births, deaths, natural reproduction, migration, depopulation

\section{INTRODUCTION}

Demographic processes in Uzbekistan are dynamic due to socio-economic factors. When analyzing demographic processes in the republic and its regions, differences in the natural conditions of the regions, economic specialization and the level of development of services directly affect population growth, changes in natural and mechanical movement. The demographic situation in the settlements created by the development of Mirzachul is developing in accordance with the age structure of the population. Also, the diversification of industries and the creation of special industrial zones leads to the emergence of a "labor flow". This, in turn, has an impact on the growth of young families and the development of demographic processes in these areas. 


\section{THE MAIN PART}

Jizzakh region also has a unique demographic situation. It can be observed that the growth rate of the population of the region, births, deaths and natural increase have changed and increased slightly compared to previous years. As of October 1, 2019, the population of the region amounted to 1374.3 thousand people, which is an increase of 331.1 thousand people or $131.7 \%$ compared to 2005 . The average annual increase in these years is $2.26 \%$.

If we analyze the population growth of the region from year to year, we can see that there are some differences. For example, in 2006 the population of the region grew by $100.8 \%$ per year (13.3 thousand people). This figure varies in the districts, with Bakhmal (102.3\%), Sharof Rashidov (102.2\%), Zarbdor (101.6\%) and Zaamin (101.5\%) districts higher than the regional average. Mirzachul (93.1\%), Zafarabad (98.3\%) and Forish (99.1\%) districts have slightly lower population growth rates.

In the statistics, we can see that population growth remained virtually unchanged from 2006-2010. However, during the following period, there were some shifts in population growth. In particular, in 2016, the population of the region increased by $102.1 \%$ year on year. In the regions, this process has accelerated, with Zarbdor (102.7\%), Bakhmal, Mirzachul (102.6\%) and Sharof Rashidov (102.4\%) districts above the regional average. Population growth is relatively slow in Arnasay (101.6\%), Dustlik and Zafarabad (101.8\%) districts. It can be seen that the process of population growth in the region has accelerated somewhat. The population has grown at different rates over the years, growing by $100.8 \%$ in 2006 compared to 2005 , and by $104.5 \%$ in $2010-2011$. In 2017, it was 103.3 percent. This means that the periodic differences in the growth rate of the province's population are not very large. But if we look at the state of this process over the last 12 years, we can see that the population has grown a bit.
When analyzing the absolute annual increase in the population of the districts in one year, an increase in the numbers since 2005 is observed. This year, the population of the region increased by 8.2 thousand people, in 2016 it amounted to 43.2 thousand people, or an increase of 35.0 thousand people. This, of course, was due to the relatively stable migration process, that, the narrowing of the differences in the migration balance and the slight increase in the birth rate. The analysis shows that in 2005 the population growth was low in Arnasay (-0.18), Zafarabad (-0.7), Zarbdor (-0.8), Mirzachul (-3.2) and Forish (0.4 ) districts. In particular, the absolute annual population growth in Mirzachul district in 2006, 2007 and 2009 was -0.9, respectively; Increased by -0.9 and -0.2 per person, respectively. Increased attention to the comprehensive socio-economic development of remote rural areas has for some time led to a decrease in internal and external migration among the population. This in turn has affected population growth.

The absolute population growth in the region and its districts in 2010 reached its maximum during the period under study (2005-2019). For example, the population of the region was 49.9 thousand people, in 2005 it was 8.2 thousand people and in 2017 it was 43.2 thousand people. 2019 increased by 29.2 thousand people compared to 2018. Also, in Jizzakh city (12.0), Gallaaral (6.6), Zarbdor (3.5) and Zaamin (12.1) districts, the absolute annual population growth was slightly higher than in other districts.

The difference in the average annual population growth (2005-2019) was due to discrepancies in the age and sex structure of the population in previous years, historical demographic situation, differences in marriages, births, deaths, migration, as well as socio-economic opportunities at different times. Therefore, in the regions where the population grew rapidly in one year, it 
increased slowly in the second year, or vice versa.

Thus, there are certain regional differences in the growth of the region's population, which differ slightly depending on the natural conditions and socio-economic development opportunities of the districts. In this regard, the following three groups can be divided in terms of population growth in the districts of the region in 2005-2016:

1. Districts with high population growth (more than 124.0\%): Zarbdor, Sharof Rashidov, Zaamin and Bakhmal districts;

2. Regions with average population growth (117.8-123.9\%): Jizzakh city, Gallaaral, Dustlik and Pakhtakor districts;

3. Territorial units with low population growth (117.7\% and less): Yangiabad, Forish, Arnasay, Zafarabad and Mirzachul districts.

In general, the population growth of the districts of the region is growing significantly compared to previous years. Natural, agroclimatic conditions also have a partial effect on population growth; favorable climatic conditions, fertile lands and sufficient water resources lead to dense population density and relatively high growth in the existing area.

The study of territorial aspects or differences in the natural movement of the population is one of the objects of study of population geography, which is also an important branch of the science of economic and social geography. In particular, an analytical analysis of demographic processes provides a clear diagnosis of the situation in the administrative-territorial units. In this case, the socio-economic processes associated with the population are studied in depth and the future situation is predicted. When analyzing the demographic processes in the republic and its regions, Jizzakh region is characterized by a high birth rate in the natural movement of the population.
If we analyze the birth rate of the population in Jizzakh region and districts, we can see that there are some differences. Between 2005 and 2016, the birth rate fluctuates differently. For example, the birth rate in the province in 2005 was 23.1 per thousand, and by 2019 it was 26.3 per thousand. During this period, the birth rate increased to 3.2 per thousand. During the period under review, the lowest birth rates were recorded in 2011 and 2012 (21.0\%). In 2005, the birth rate in Sharof Rashidov (25.1\%), Mirzachul (25.0\%), Zafarabad (24.1\%) and Forish (23.4\%) districts was higher than the regional average $(23.1 \%)$. The lowest rates are observed in Jizzakh (18.1 $\%$ ) and Pakhtakor (18.9\%) districts. Analyzing the situation in 2019, Bakhmal (30.4\%) Sharof Rashidov (28.4\%), Zaamin (28.2\%), Zarbdor (27.6\%) and Gallaorol (27.2\%) districts of the region $(26.3 \%$ ) was higher than the average, while the lowest rates were in Mirzachul (21.0 $\%)$, Zafarabad (22.4 \%) and Forish (23.3\%) districts.

During 2005-2019, Sharof Rashidov district is characterized by a high birth rate. Due to the fact that the district directly surrounds the regional center, the development of public services is more densely populated. In particular, the operation of the Jizzakh Special Industrial Zone has led to an "influx" of young professionals. Naturally, the birth rate will be higher in young families. Bakhmal district also has the highest birth rate $(30.4 \%)$. The fact that the population of the district has long been engaged in agriculture and animal husbandry and is more sedentary than in other districts of the region, the small difference in the migration balance leads to a relatively rapid population growth.

During the years of study in the city of Jizzakh, the relatively low birth rate is formed in accordance with the socio-economic conditions. The employment of women in social life, the housing problem, the relatively 
high rate of migration, and the inclusion of able-bodied young people are all affected.

In Mirzachul district, the birth rate is low (21.0 $\%$ ) during the analyzed years. The decline in the level of socio-economic development of the district in recent years, deficiencies in infrastructure, deterioration of land reclamation, changes in the economic system in some cases lead to population migration. This in turn has a direct impact on demographic processes.

\section{RESULTS AND DISCUSSIONS}

Based on the study of the regional characteristics of births, we can divide the Jizzakh region and districts in 2005-2019 into the following groups:

- Districts with high birth rate $(24.2 \%$ and more): Zarbdor, Bakhmal, Sharof Rashidov.

- Birth rate is average in the regions (22.8$24.1 \%$ ): Dostlik, Forish, Gallaaral and Zaamin districts.

- Areas with low birth rates (22.7\% and less): Jizzakh city, Mirzachul, Pakhtakor, Arnasay, Zafarabad and Yangiabad districts.

- When studying demographic processes, special attention should be paid to deaths. Natural population growth also depends on the mortality rate. In this regard, there are some differences depending on the socio-economic development, demographic situation and environmental situation of the regions. Some inconveniences in the living conditions of the population and incomplete provision of clean drinking water also lead to a certain increase in deaths. This is especially true for desert and foothill areas.

According to B.S. Urlanis, a well-known Russian demographer on population mortality and its causes, has this to say: "Death can be at different levels. Every born eventually dies. There is a saying that a baby's first step is the first step he takes to death. But the end of this situation will be different. Life expectancy varies from a few seconds to 100 years or more."

When analyzing mortality rates at the national level, the lowest rates were recorded in Jizzakh region. At the level of the province and its districts, the situation in the years under study has a small distinction when analyzed. In 2005, the mortality rate in the region was 4.2 per thousand, while in Bakhmal (4.8\%), Gallaorol (4.8), Zaamin (4.8), Forish (4.6) and Yangiabad (4.6\%) districts. above the regional average. The lowest rates are observed in Arnasay and Dustlik districts (2.8 $\%$ ). During the study period, Bakhmal and Gallaorol districts stood out from the rest with high mortality rates. At the same time, the fact that most of the area of both districts are mountainous and hilly, led to the ribbon-like distribution of the population along the rivers. It is known that, depending on the location of the population, it creates certain barriers to the organization of medical services and some infrastructure outlets. It limits the provision of transport services in different weather conditions. It may also be a sign that the death rate is high in some cases, such as the return of veterans involved in the development of protected and gray lands to their homelands.

With the development of new lands, Mirzachul, the settlements built in a planned way will be densely populated. Naturally, it is convenient to organize public services in these areas. In particular, the provision of medical services, integrated medical facilities, pharmacies, etc., indicates a relatively low mortality rate among the population.

Statistical analysis shows that in the years under review, the differences in mortality rates at the district level are not large. However, in order to see more clearly the differences in this situation, we can divide the 
Jizzakh region and districts into the following groups according to the mortality rate for 2005-2019:

Districts with high mortality rates $(4.2 \%$ and more): Zaamin, Forish, Yangiabad, Bakhmal and Gallaorol districts;

The average mortality rate is 3.6-4.1 \%: Jizzakh, Zarbdor, Pakhtakor and Sharof Rashidov districts;

Areas with low mortality rates (3.5\% and less): Arnasay, Dustlik, Zafarabad and Mirzachul districts.

The grouping of districts by natural reproduction rate in the province repeats the grouping based on birth rates.

\section{SUMMARY PART}

In summary, based on the above, the following can be noted:

- The demographic situation in the region is growing;

- The relative stability of the migration process, that is the reduction of differences in the migration balance and a slight increase in the birth rate.

So, at present, the natural increase of the population in the region is mainly determined by the birth process. Population growth is increasing due to its natural increase. Migration processes in the region are more stable than in other regions.

\section{REFERENCES}

1. Soliev A., Burieva M., Nazarov M., Mukhamedov O. and b. Demography of rural areas.-T : National University of Uzbekistan, 2005.-139 p.

2. Data of the Statistics Department of Jizzakh region. 2016.

3. Lapasovich, M. O., Nematovich, N. O., Yakubovich, Z. B., Rustamovich, U. M., \&
Tolipov, F. (2020). HISTORICAL AND ETHNOGRAPHIC CHARACTERISTICS AND SOCIO-SPIRITUAL FACTORS OF VISITING TOURISM IN UZBEKISTAN. Journal of Critical Reviews, 7(6), 47-50.

4. Gudalov, M. (2019). Foundation of AydarArnasay lakes system and their effects on the environmental landscape. Nature and Science, 17(11).

5. Sh, S., Gudalov, M., \& Sh, S. (2020). Geolologic situation in the Aydar-Arnasay colony and its atropny. Journal of Critical Reviews, 7(3).

6. Mirkomil, G., \& Bakhtiyor, Z. (2020). METHODS OF STUDYING THE LANDSCAPES AROUND THE AYDAR-ARNASAY LAKE SYSTEM. International Engineering Journal For Research \& Development, 5(7), 5-5.

7. Nazarov, A. (2020). History Of The Emergence And Development Of Scientific Societies In The Governor-General of Turkestan. The American Journal of Social Science and Education Innovations, 2(10), 82-88.

8. Kariev, A., \& Aminov, H. (2020). New information about Imam al-Zarnūji and his work "Ta'līm al-Muta'allim". Solid State Technology, 63(6), 2372-2387.

9. Rasuljanovna, I. N., \& Rakhmonqulovich, K. N. (2020). Trade Relations Between Ancient Bacteria And China On The II-I BC. The American Journal of Social Science and Education Innovations, 2(07), 47-51. 